\title{
PERANCANGAN WEBCOMIC SEBAGAI PANDUAN MENJADI SEORANG COSPLAYER BAGI REMAJA USIA 15-25 TAHUN
}

\author{
Swesti Anjampiana Bentri, S.Tr.Sn., M.Sn ${ }^{1}$ \\ Restu Hendriyani Magh'firoh, S.Pd., M.Pd ${ }^{2}$ \\ Olivia Irene Britney Tahitu ${ }^{3}$
}

\author{
Institut Informatika Indonesia, Surabaya ${ }^{I}$ \\ swesti@ikado.ac.id
}

\begin{abstract}
Abstrak
Cosplay (コスプレ, kosupure) merupakan singkatan dari “costume” dan "play" yang artinya bermain dengan kostum. Dengan perkembangan cosplay yang berkembang di Indonesia dan juga adanya sebuah komunitas, masih banyak cosplayer awam yang belum paham apa saja yang harus disiapkan. Oleh karena itu webcomic ini dirancang untuk memberikan informasi mengenai apa saja yang dibutuhkan untuk mengembangkan dan mendalami cosplay. Pada perancangan ini menggunakan metode penelitian kualitatif (observasi dan wawancara) dengan cosplayer berpengalaman dan ketua komunitas cosplay di Surabaya. Proses perancangan dimulai dari mencari ide/refrensi, menulis cerita, mendesain karakter, sketsa komik, digitalisasi dan mengatur layout, lalu diunggah. Komik 10 episode yang diunggah ke LINE Webtoon, tersebut menceritakan tentang seseorang yang ingin menjadi cosplayer tetapi belum tahu apa saja yang harus disiapkan. Selain itu terdapat media pendukung yang berfungsi untuk menjangkau audiens seperti Instagram, stiker WhatsApp, kaos, tote bag, pouch, notebook, bantal, masker, gantungan, dan tumbler. Komik ini diharapkan dapat menyampaikan informasi melalui cerita yang dibuat, mulai dari pengenalan hingga membawa cosplay tersebut ke event.
\end{abstract}

Kata kunci: cosplay, webcomic, informatif, remaja

\begin{abstract}
Cosplay (コスプレ, kosupure) stands for "costume" and "play" which means to play with costumes. With the development of cosplay growing in Indonesia and also the existence of a community, there are still many beginner cosplayers who do not understand what to prepare. This webcomic is therefore designed to provide information on what is needed to develop and explore cosplay. This design uses qualitative research methods (observations and interviews) with experienced cosplayers and leaders of the cosplay community in
\end{abstract}


Surabaya. The design process starts from looking for ideas/references, writing stories, designing characters, sketching comics, digitizing and arranging layouts, then uploading them. The 10-episode comic uploaded to LINE Webtoon, tells the story of someone who wants to become a cosplayer but doesn't know what to prepare. In addition, there are supporting media that function to reach audiences such as Instagram, WhatsApp stickers, t-shirts, tote bags, pouches, notebooks, pillows, masks, hangers, and tumblers. This comic is expected to convey information through the stories that are made, starting from the introduction to bringing the cosplay to the event.

Keywords: cosplay, webcomic, informative, teenager

\section{PENDAHULUAN}

Cosplay (コスプレ, kosupure) merupakan singkatan dari “costume” dan "play" yang artinya bermain dengan kostum. Cosplay merupakan kegiatan yang menirukan sebuah karakter dari anime, manga/komik, game, kartun, film, tokoh terkenal, dengan cara memakai kostum, rambut palsu, sepatu, dan aksesoris pelengkap lainnya. Sedangkan orang yang sedang melakukan cosplay disebut sebagai cosplayer atau disingkat menjadi coser.

Dengan perkembangan cosplay yang berkembang di Indonesia dan juga adanya sebuah komunitas, masih banyak cosplayer awam yang belum paham apa saja yang harus disiapkan. Hal itu bisa membuat cosplayer kebingungan atau tidak percaya diri dengan cosplay yang dibawakan. Permasalahan lain yang dihadapi adalah kurangnya pengetahuan akan karakter yang sedang di-cosplay-kan, akhirnya menjadi out of character. Contohnya seperti rambut palsu tidak distyling atau warna rambut palsu berbeda, kelengkapan aksesoris kurang, makeup tidak sesuai. Dalam wawancara yang dilakukan dengan Nekonoi Katsu tentang permasalahan yang biasa muncul saat pertama kali ber-cosplay, biasanya karena kurangnya pengalaman, kurangnya informasi dalam membeli kebutuhan cosplay, kurangnya ilmu dalam membuat properti.

Agar dapat membantu dan memberikan informasi tentang apa saja yang harus dipersiapkan untuk menjadi cosplayer secara jelas diperlukan media yang mudah untuk dipahami dan menarik bagi target audiens. Dengan kemajuan teknologi sekarang sangat mudah jika ingin mendapatkan informasi atau sekedar 
membaca. Berdasarkan hasil penelitian Perpustakaan Nasional tahun 2017 oleh Puan Maharani mengungkapkan bahwa rata-rata orang Indonesia hanya membaca buku 3-4 kali per minggu dengan durasi waktu membaca per hari rata-rata 30-59 menit, Maka dari itu diperlukan media penunjang seperti gambar dan ilustrasi agar menarik minat pembaca. Komik merupakan salah satu media komunikasi visual yang di dalamnya terdapat teks dan gambar, maka komik merupakan media yang tepat untuk menyampaikan informasi, selain itu komik/manga dan cosplay juga merupakan bagian dari pop kultur Jepang yang popular di Indonesia (jeducation.co.id, 10 Januari 2020) dan saling berhubungan yang secara kemungkinan akan menarik perhatian audiens untuk melihat media yang dibuat penulis. Media komik merupakan media yang mempunyai sifat sederhana, jelas, mudah dipahami dan lebih bersifat personal sehingga bersifat informatif dan edukatif, selain itu alasan memilih rentan usia 15-25 tahun dikarenakan menurut pengamatan penulis selama menjadi cosplayer rata-rata usia untuk mulai cosplay dimulai pada usia tersebut, hal itu juga ditunjang oleh jawaban wawancara dengan Jerry selaku ketua komunitas COSURA dimana usia rata-rata anggota yang bergabung mulai dari usia 15-30 tahun.

Seiring kemajuan teknologi, komik juga mengikuti perubahan tersebut, dimana komik sudah bisa dibaca/diakses melalui internet. Karena mudahnya akses untuk membaca, hal ini menarik minat masyarakat untuk membaca ataupun membuat komik online.

Berdasarkan penjelasan tersebut dapat disimpulkan bahwa media yang membantu cosplayer masih kurang terlebih lagi jika memulai cosplay secara mandiri, penulis berharap agar cosplayer awam dan juga masyarakat umum yang membaca atau mengakses media yang dirancang dalam bentuk webcomic tersebut dapat menerima informasi mengenai pengenalan, kebutuhan untuk cosplay, cara menjadi cosplayer, permasalahan dan solusi, kegiatan yang dilakukan saat bercosplay, hingga membawa cosplay tersebut ke event yang dikemas secara informatif dan menarik, penulis memakai genre slice of life agar dapat disesuaikan dengan kegiatan sehari-hari yang ada. Selain media utama, terdapat media pendukung yang berfungsi untuk menjangkau audiens secara luas. 


\section{KAJIAN TEORI}

\section{Pengertian Cosplay}

Cosplay (コスプレ, kosupure) merupakan istilah Bahasa inggris dari "costume" dan "play". Istilah cosplay diciptakan oleh reporter Jepang yang bernama Nobuyuki Takahashi dari Studio Hard ketika menghadiri World Science Fiction Convention (Worldcon) di Los Angeles,California pada tahun 1984.

Cosplay bukan sepenuhnya penemuan dari Jepang, tetapi pesta kostum dan masquerade telah populer sejak abad ke-15 dan cosplayer pertama tersebut adalah Myrtle Rebecca Douglas Smith Gray Nolan yang dikenal dalam sejarah fiksi ilmiah secara sederhana sebagai Morojo. Douglas merupakan penggemar fiksi ilmiah, penerbit majalah fanzine, dan pelopor cosplay dari Los Angeles, California. Di tahun 1939 Douglas menghadiri World Science Fiction Convention (Worldcon) ke-1 di New York City mengenakan kostum futuristic, termasuk jubah hijau dan celana pendek, berdasarkan karya seni majalah pulp karya Frank R. Paul dan film Things to Come, kostumnya dirancang, dibuat, dan dijahit Douglas sendiri. (japanesestation.com, 20 Juli 2020).

\section{Teori Komik}

Secara umum komik merupakan salah satu media yang berfungsi untuk menyampaikan cerita melalui ilustrasi gambar untuk pendeskripsian cerita tersebut. Istilah komik berasal dari bahasa Yunani yang artinya komikus, dalam bahasa Perancis disebut comique, lalu untuk bahasa inggris dikenal dengan sebutan comic. Menurut Kamus Besar Bahasa Indonesia (KBBI), komik merupakan suatu cerita bergambar yang memiliki sifat mudah dicerna dan lucu.

Adapun definisi komik menurut para ahli, Menurut Hurlock (1978), komik merupakan sebuah media yang dapat memberikan model yang dapat digunakan untuk meningkatkan dan mengembangkan kepribadian anak. Komik juga dapat dijadikan sebagai sarana komunikasi, sarana untuk menyampaikan cerita, pesan, dan bahkan sampai hal-hal yang berbau ilmiah sekalipun seperti halnya genre sastra anak yang lainnya.(hot.liputan6.com, 28 Mei 2021) 
Menurut Franz dan Meier (1994:55), komik adalah suatu cerita yang bertekanan pada gerak dan Tindakan yang ditampilkan lewat urutan gambar yang dibuat secara khas dengan paduan kata-kata.(hot.liputan6.com, 28 Mei 2021)

Menurut Scott McCloud (2002:9) komik adalah kumpulan gambar yang berfungsi untuk menyampaikan informasi atau menghasilkan respon estetik bagi yang melihatnya. Seluruh teks cerita dalam komik tersusun secara rapi dan saling berhubungan antara gambar (lambing visual) dengan kata-kata (lambang verbal). Gambar di dalam sebuah komik diartikan sebagai gambar-gambar statis yang tersusun secara berurutan dan saling berkaitan antara gambar yang satu dengan gambar yang lain sehingga membentuk sebuah cerita.(hot.liputan6.com, 28 Mei 2021)

Menurut Sudhana dan Rifai (2011) komik dapat dipergunakan sebagai bahan ajar karena dapat mengefektifkan proses belajar mengajar, meningkatkan minat belajar siswa, dan menimbulkan minat apresiasi siswa.(hot.liputan6.com, 28 Mei 2021)

\section{Teori Webtoon}

Pada dasarnya komik digital adalah jenis komik yang tersedia dalam bentuk elektronik yang dapat diakses menggunakan HP, tablet, ataupun komputer. Pembuatan webtoon memiliki beberapa langkah yang kurang lebih sama dengan pembuatan komik manual. Terdapat beberapa hal yang dapat diperhatikan agar webtoon tersebut menarik perhatian pembaca (webtoons.com, 3 Februari 2020):

\section{Thumbnail dan Cover yang Menarik}

Agar menarik perhatian pembaca hal pertama yang dapat dilakukan adalah membuat thumbnail dan cover yang menarik.

\section{Tiga Episode Pertama}

Perlu dipersiapkan premis dalam sebuah cerita yang kemudian dikembangkan menjadi tiga episode pertama, agar pembaca penasaran dengan kelanjutan dari webtoon tersebut.

\section{Cliffhanger}


Teknik mengakhiri episode dengan akhiran yang menggantung disebut cliffhanger, hal ini menjadi cara yang efektif untuk membuat pembaca kembali membaca kelanjutannya.

4. Riset

Selain hal-hal diatas, diperlukan juga sebuah riset terlebih dahulu mengenai cerita webtoon yang akan diangkat agar dalam pembuatan cerita lebih mendetail.

5. Membuat Jadwal

Agar dapat mengerjakan webtoon secara maksimal, akan lebih baik jika membuat dan menepati jadwal dari jam tayang webtoon.

teori berisi penjelasan tentang teori yang relevan dengan masalah penelitian.

\section{Teori Ilustrasi}

Dalam Kamus Besar Bahasa Indonesia (KBBI) ilustrasi merupakan gambar (foto, lukisan) untuk membantu memperjelas isi buku, karangan, dan sebagainya. Terdapat beberapa definisi ilustrasi menurut para ahli (freedomnesia.id, 11 juni 2019), menurut Rohidi (1984:87) ilustrasi merupakan penggambaran suatu elemen rupa guna menjelaskan, menerangkan, dan memperindah sebuah teks, agar pembaca dapat merasakan secara langsung melalui mata sendiri, sifat, dan kesan yang ada dalam cerita yang disajikan.

Menurut Soedarso (1990:1) ilustrasi merupakan seni lukis atau seni berbentuk gambar yang di abadikan untuk kepentingan lain,yang bisa memberikan penjelasan dan mengiringi suatu pengertian, contohnya cerita pendek dalam sebuah majalah.

Menurut Fariz (2009:14) ilustrasi, sebagai bentuk ekspektasi dari ketidakmungkinan dan tak ada yang berbeda jauh seperti halnya angan-angan, yang bersifat virtual atau maya, serta hadir dalam sebagai diverikasi.

\section{Pengertian Remaja}

Pengertian remaja menurut Soetjiningsih (2004, seperti yang dikutip oleh Novi, 2020) merupakan masa peralihan dari masa kanak-kanak dan masa dewasa, yang dimulai saat terjadinya kematangan seksual, yaitu usia 11 atau 12 tahun 
sampai dengan 20 tahun. Menurut WHO, mereka yang berada pada tahap transisi antara masa kanak-kanak dan dewasa disebut sebagai remaja, sedangkan untuk batasan usianya ada pada 12 sampai 24 tahun. Sedangkan pengertian remaja menurut Peraturan Menteri Kesehatan RI Nomor 25 tahun 2014 remaja adalah penduduk dalam rentang usia 10 sampai 18 tahun. Rentang usia remaja menurut Badan Kependudukan dan Keluarga Berencana Nasional (BKKBN) adalah 10 sampai 24 tahun serta belum menikah.

\section{METODE PENELITIAN}

Metode penelitian yang digunakan pada perancangan webcomic sebagai panduan menjadi seorang cosplayer bagi remaja usia 15-25 tahun ini adalah metode kualitatif, yaitu observasi dan wawancara.

Wawancara dilakukan dengan 3 cosplayer berpengalaman dan ketua komunitas COSURA untuk mengetahui persiapan dalam ber-cosplay dan juga seperti apa cosplay di kalangan masyarakat. Sedangkan observasi dilakukan dengan menganalisa komparator dari media yang sejenis untuk mengetahui cara menyampaikan informasi melalui komik dan juga penyusunan layout yang tepat.

Selain data primer, terdapat juga data sekunder yang didapat dari studi pustaka melalui buku ataupun internet, dokumentasi data dari cosplayer dan ketua komunitas COSURA yang berfungsi untuk memperkuat data yang berkaitan dengan panjuan menjadi seorang cosplayer.

\section{HASIL DAN PEMBAHASAN}

Penulis merancang webcomic sebagai panduan untuk menjadi seorang cosplayer, yang di dalamnya memuat informasi mengenai pengenalan, kebutuhan untuk cosplay, cara menjadi cosplayer, permasalahan dan solusi, kegiatan yang dilakukan saat ber-cosplay, hingga membawa cosplay tersebut ke event yang dikemas secara informatif dan menarik.

Menggunakan media webcomic karena perlunya media penunjang seperti gambar dan ilustrasi, media komik merupakan salah satu media komunikasi visual yang di dalamnya terdapat teks dan gambar, sekaligus merupakan media yang 
mempunyai sifat sederhana, jelas, mudah dipahami dan lebih bersifat personal sehingga bersifat informatif dan edukatif. Perancangan ini menggunakan style manga menyesuaikan dengan jenis cosplay yang diangkat yaitu anime/manga, dan ditujukan untuk remaja usia 15-25 tahun.

\section{Judul Komik}

Pada webcomic yang dibuat menceritakan tentang seseorang yang tertarik untuk mencoba cosplay tetapi masih bingung dengan apa saja yang harus dipersiapkan. Mulai dari pengenalan cosplay, kebutuhan untuk cosplay, cara menjadi cosplayer, permasalahan dan solusi, kegiatan yang dilakukan saat bercosplay, hingga membawa cosplay tersebut ke event. Oleh karena itu judul yang diangkat untuk webcomic ini adalah "Guide to Cosplay" yang bertujuan untuk memberi panduan/petunjuk bagi orang awam yang ingin memulai/mencoba cosplay.

\section{Logo}

Desain final dari perancangan logo Guide to Cosplay. Topeng dari logo yang terpilih menggambarkan seseorang yang sedang menjadi orang lain, seperti cosplay yang menjiwai sebuah karakter baik dari penampilan ataupun sifat. Bentuk topeng tersebut dibubuhi dengan tulisan yang merupakan judul dari karya komik. Logo tersebut diaplikasikan pada tiap episode dari webtoon Guide to Cosplay dan juga pada media pendukung seperti Instagram, tote bag, pouch, notebook, bantal, masker, gantungan, dan botol tumbler.

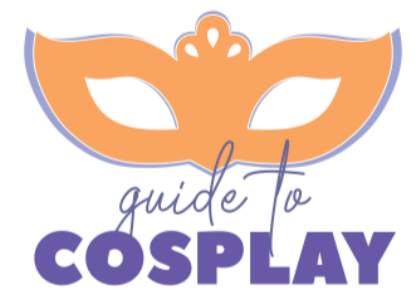

Gambar 1. Logo Guide to Cosplay 


\section{Webtoon}

Pada perancangan ini karya dari media utama diunggah ke platform LINE Webtoon Kanvas. Dimana dapat diakses dan dibaca oleh semua orang dan kalangan terutama remaja usia 15-25 tahun.

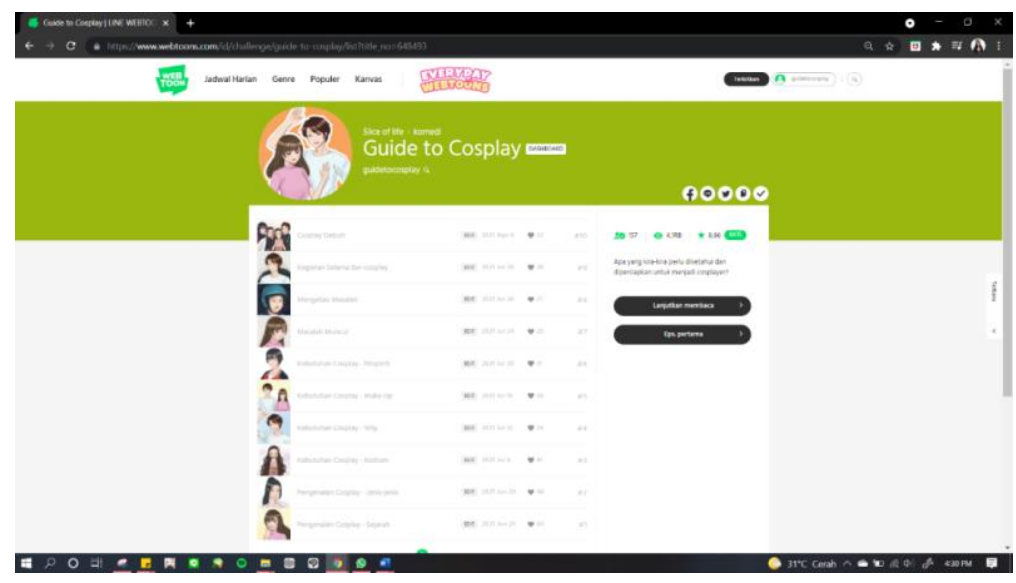

Gambar 2. Webtoon Versi Desktop

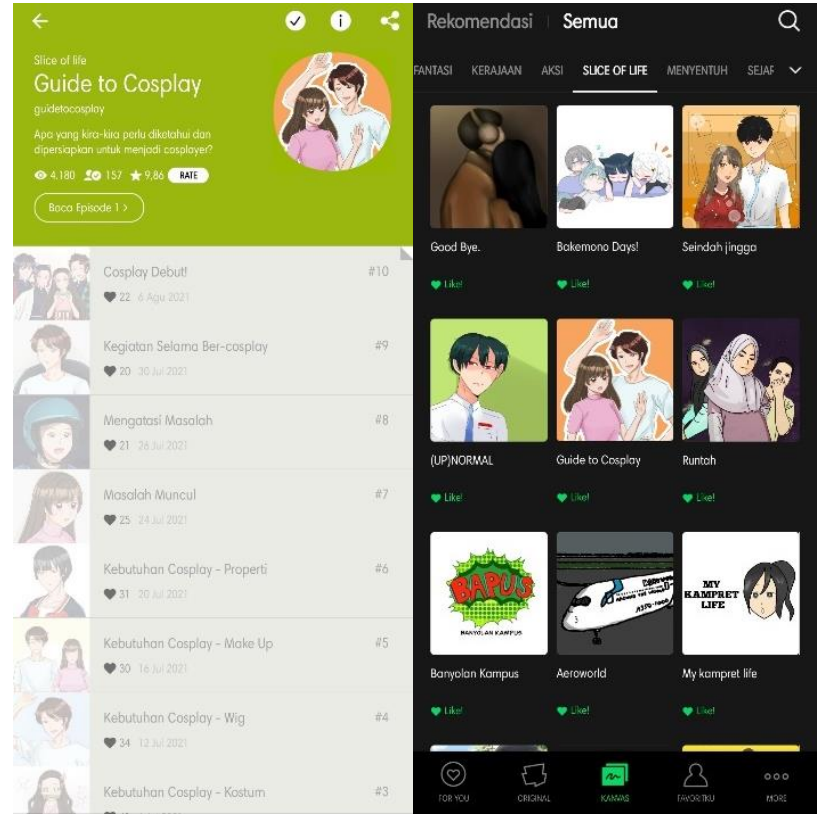

Gambar 3. Webtoon Versi Mobile 


\section{Episode}

Pengerjaan episode pada webtoon ini dikerjakan secara memanjang ke bawah, karena memakai sistem scrolling. Pada teks percakapan menggunakan typeface Laffayette Comic Pro karena selain nyaman untuk dibaca typeface tersebut sering digunakan dalam penggunaan teks di komik digital. Genre yang digunakan dalam komik ini adalah Slice of Life ditambah dengan sedikit humor dan romance. Dalam menjelaskan informasi, menggunakan gambar-gambar visual yang mendukung agar pembaca dapat memvisualisasikan informasi yang ingin di sampaikan.

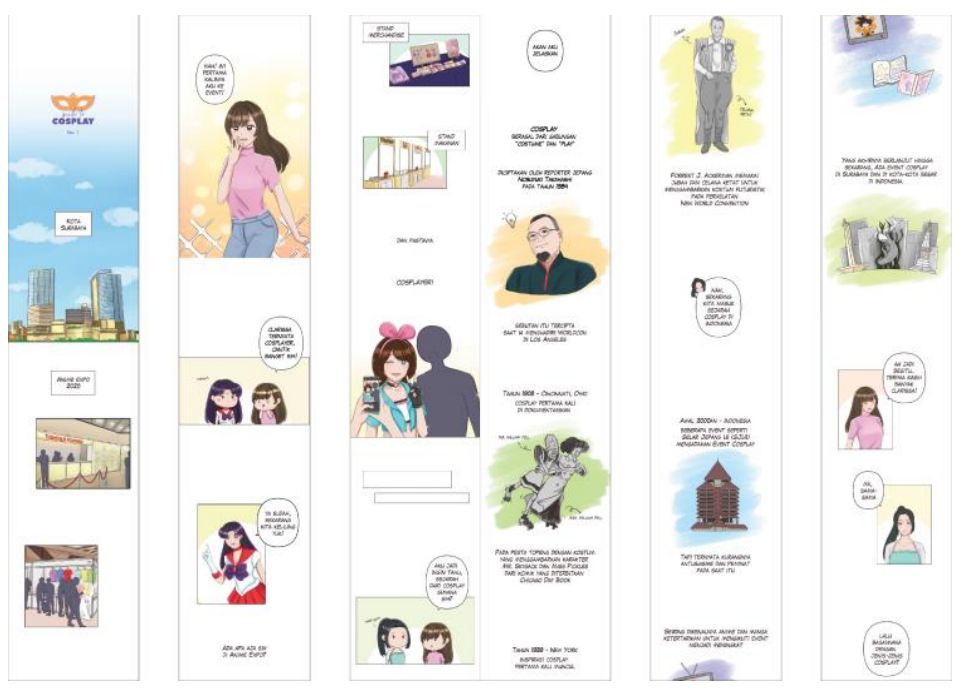

Gambar 4. Episode 1

\section{Media Pendukung}

Media pendukung berfungsi untuk mempromosikan Webtoon Guide to Cosplay dan juga menjangkau audiens. Dalam perancangan ini menggunakan 10 media pendukung yaitu Instagram, stiker WhatsApp, kaos, tote bag, pouch, notebook, bantal, masker, gantungan, dan botol tumbler.

\section{A. Instagram}

Id yang digunakan pada Instagram adalah @ guidetocosplay, Instagram ini berfungsi untuk memberikan informasi tambahan mengenai cosplay yang tidak ada di webtoon. 


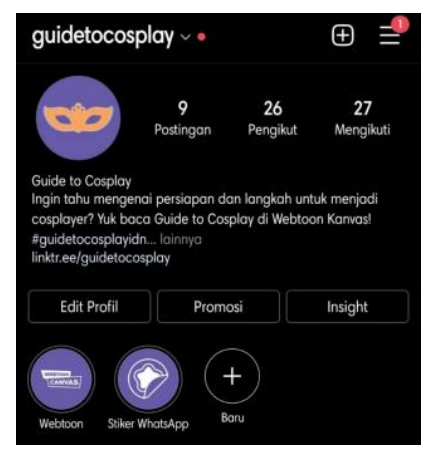

Gambar 4. Instagram

\section{B. Stiker WhatsApp}

Berjumlah 8 dan memiliki batas ukuran 512x512px. Didapatkan dari link yang ada di highlight Instagram.

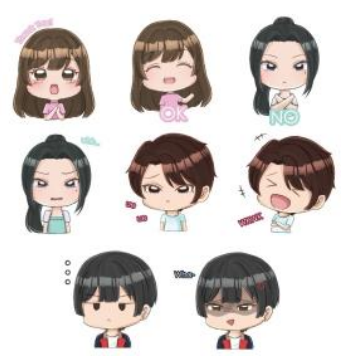

Gambar 5. Stiker WhatsApp

\section{Kaos}

Berbahan cotton combed berwarna hitam dan putih. Didapatkan dari giveaway dan penjualan yang diadakan di Instagram dengan harga Rp60.000,00.

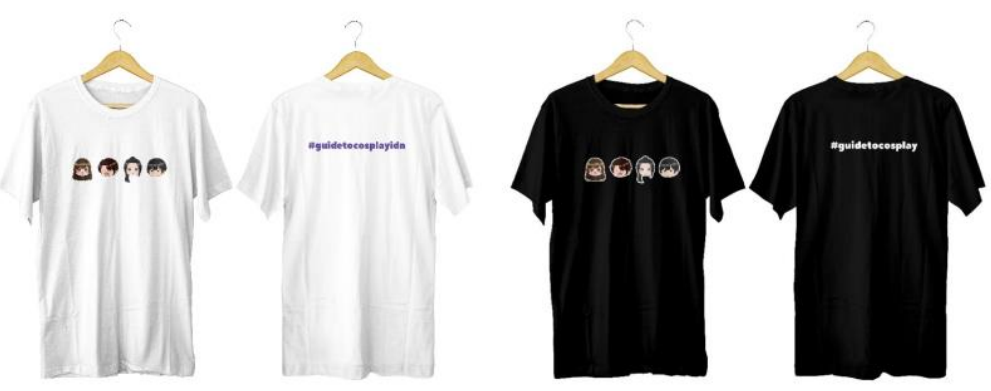

Gambar 6. Kaos 2 Versi 


\section{Tote Bag}

Berukuran $35 \times 40 \mathrm{~cm}$ berbahan kanvas dan dicetak dengan teknik DTG print. Memakai desain karakter dari webtoon Guide to Cosplay beserta logonya. Didapatkan dari giveaway yang diadakan di Instagram.

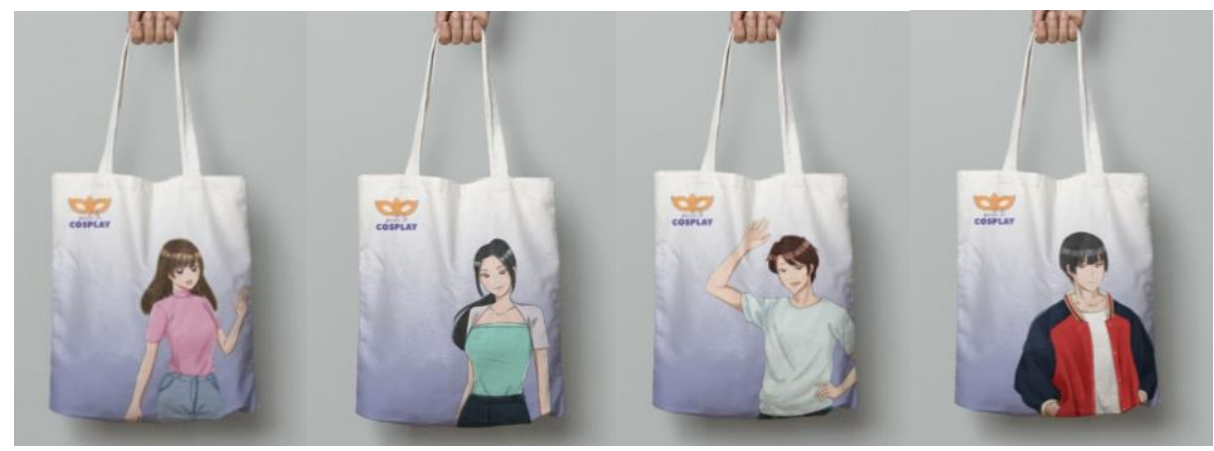

Gambar 7. Tote Bag 4 Versi

\section{E. Pouch}

Berukuran 19x12 cm berbahan kulit kanvas yang dicetak dengan teknik DTG print. Didapatkan dari penjualan lewat Instagram dengan harga Rp45.000,00.
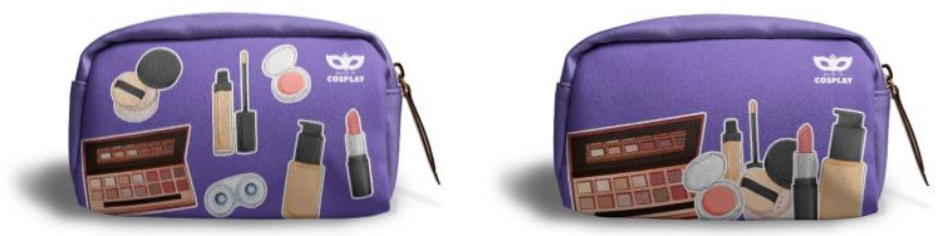

Gambar 8. Pouch 2 Versi

\section{F. Notebook}

Memiliki ukuran A5 dengan hardcover dan bagian dalam buku polos. Di dapatkan melalui giveaway di Instagram.

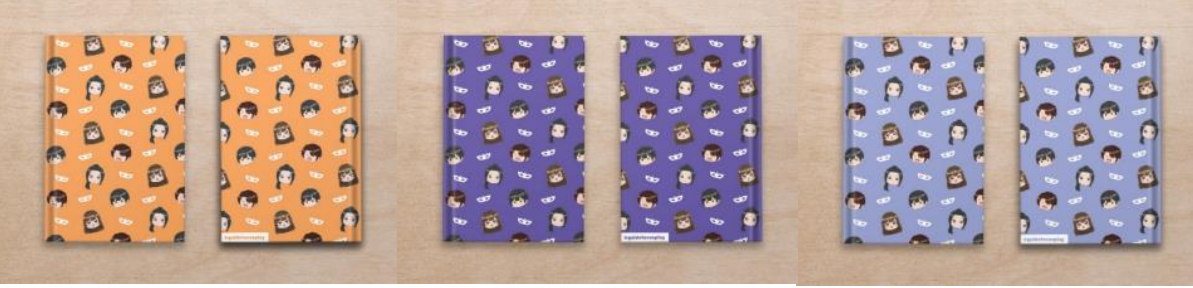

Gambar 9. Notebook 3 Versi 


\section{G. Bantal}

Berukuran $35 \times 35 \mathrm{~cm}$ berbahan katun. Di dapatkan dari penjualan di Instagram dengan harga Rp120.000,00.

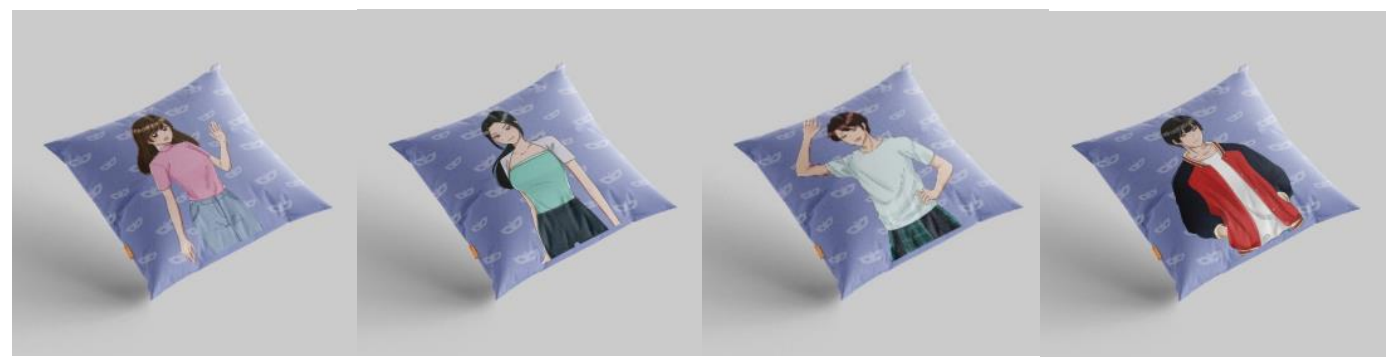

\section{Gambar 10. Bantal 4 Versi}

\section{H. Masker}

Masker 3 lapis dengan model earloop. Di dapatkan dari giveaway dan penjualan melalui Instagram dengan harga Rp35.000,00.

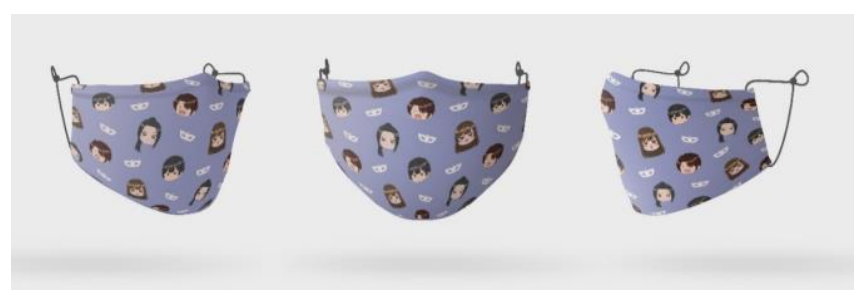

Gambar 11. Masker Kain

\section{Gantungan}

Gantungan kunci berbahan akrilik yang bergambar logo dari "Guide to Cosplay".

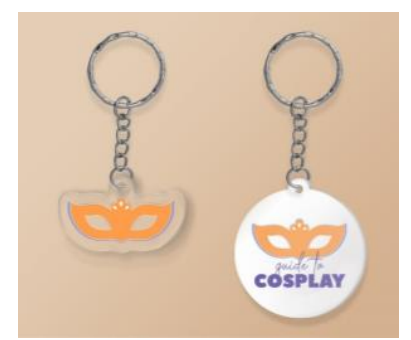

Gambar 12. Gantungan 2 Versi 


\section{J. Botol Tumbler}

Botol Tumbler yang dipakai berukuran $450 \mathrm{ml}$ dengan jenis acrylic double wall. Dijual melalui Instagram dengan harga Rp180.000,00

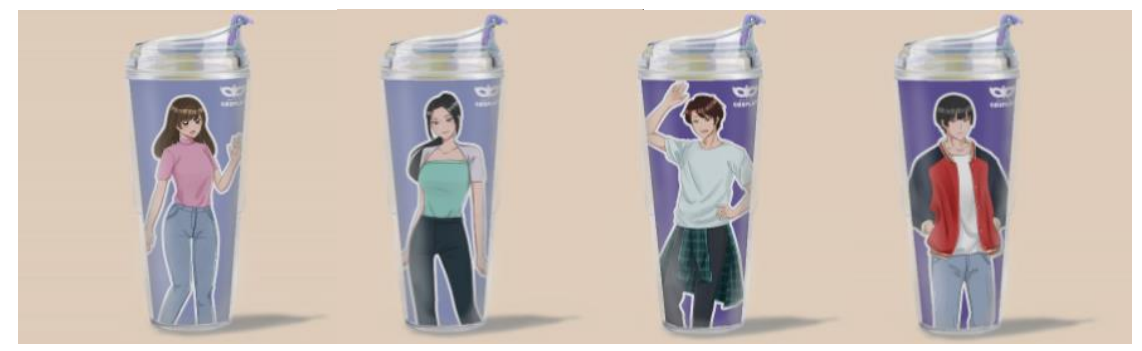

Gambar 13. Botol Tumbler 4 Versi

\section{SIMPULAN DAN SARAN}

\section{Simpulan}

Perancangan webcomic yang dibuat sebagai panduan menjadi seorang cosplayer bertujuan untuk memberikan informasi kepada cosplayer/orang awam apa saja yang dibutuhkan untuk mengembangkan dan mendalami cosplay. Dengan memanfaatkan media seperti webcomic yang dapat menjangkau banyak pembaca cukup efektif, namun tetap perlu diperhatikan dalam penyusunan cerita agar materi tetap bisa dihubungkan dengan alur cerita dan tersampaikan dengan baik.

Selain itu melalui media tersebut maka tanggapan para pembaca baik itu dukungan ataupun kritik dan saran dapat langsung dilihat, yang digunakan untuk memperbaiki kualitas komik kedepannya. Dalam proses perancangan webcomic tentang cosplay, banyak sekali hal yang dapat dibahas lebih dalam dan dikembangkan baik dari tema maupun penyajian namun tidak dapat dibahas dalam perancangan ini. Pembahasan dan pengembangan dari tema ini dibutuhkan agar audiens dapat lebih memahami dan mendalami cosplay. Diharapkan dengan adanya perancangan ini dapat membantu cosplayer ataupun orang awam dalam melakukan cosplay

\section{Saran}

Pembuatan karya komik dengan memanfaatkan platform perlu memerhatikan format/ketentuan yang diberikan dari pihak platform dalam proses mengunggah komik digital, seperti thumbnail untuk webtoon, deskripsi/sinopsis 
komik, thumbnail untuk setiap episode, format dan ukuran gambar yang diunggah, dimensi/kanvas gambar. Pengaturan jadwal dan pemantauan perkembangan proses disetiap harinya juga perlu diperhatikan. Hal ini digunakan untuk memastikan bahwa materi yang dimuat dalam komik dapat tersampaikan dengan baik dan tidak berkembang terlalu luas, sehingga tidak keluar dari bahasan utama. Pengembangan alur cerita yang terlalu lebar akan mengakiatkan cerita komik cenderung lepas dari pokok bahasannya. Komitmen dalam pembuatan komik sesuai tema dan pokok bahasan sangat membantu untuk menjaga isi cerita tetap pada jalurnya.

Tema Cosplay sendiri masih sangat menarik untuk dijadikan pembahasan dan dikembangkan lagi, mengingat perkembangan peminat cosplay di Indonesia dapat dikatakan baik. Pemilihan tema yang sejenis ini dapat dikembangkan pada bentuk karya yang lainnya. Hal ini dikarenakan masih kurangnya karya yang mengangkat tema-tema cosplay.

\section{DAFTAR PUSTAKA}

Andina, Yurista. n.d. Apa Itu Webtoon? Komik Kekinian Favorit Milenial. Diakses dari https://kreativv.com/seni-rupa-dan-desain/apa-itu-webtoon/ Pada tanggal 4 Februari 2021 pukul 17.00 WIB

Asano, Vie. (2014). Inilah Asal Usul Istilah "Cosplay". Diakses dari https://japanesestation.com/anime-manga/cosplay/inilah-asal-usul-istilahcosplay Pada tanggal 17 Februari 2021 pukul 14.20 WIB

Evelyn. (2020). Mengenal Cosplay, Budaya Poupler Jepang yang Dicintai Banyak Orang. Diakses dari https://japanesestation.com/culture/history/mengenalcosplay-budaya-populer-jepang-yang-dicintai-banyak-orang Pada tanggal 4 Februari 2021 pukul 14.20 WIB

Jeducation. (2020). Mengenal 5 maca, Japan Pop Culture yang populer di Indonesia. Diakses dari https://jeducation.co.id/5-macam-japan-pop-culture/ Pada tanggal 4 Februari 2021 pukul 16.08 WIB

Larasati, Novi Hardita. (2020). Pengertian Remaja Menurut Para Ahli dan WHO. Diakses dari https://www.diadona.id/family/pengertian-remaja-menurutpara-ahli-dan-who-200530i.html Pada tanggal 24 Februari 2021 pukul 11.49 WIB

Poer. (2019). ILUSTRASI: Gambar Untuk Memperjelas Tulisan. Diakses dari https://www.freedomnesia.id/ilustrasi/ Pada tanggal 20 April 2021 pukul $20.50 \mathrm{WIB}$

Ramadhan, Wahyu. n.d. Jenis-jenis Komik, dari Novel Grafis hingga Webtoon. Diakses dari https://kreativv.com/jenis-jenis-komik/ Pada ttanggal 7 September 2021 pukul 17.00 WIB

Riadi, Muchlisin. (2020). Komik (Pengertian, Unsur, Jenis dan Teknik Pembuatan). Diakses dari https://www.kajianpustaka.com/2020/08/komik- 
pengertian-unsur-jenis-dan-teknik-pembuatan.html Pada 4 Februari 2021 pukul 20.35 WIB

Tysara, Laudia. (2021). Pengertian Komik Menurut Para Ahli, Lengkap Contohcontohnya. Diakses dari https://hot.liputan6.com/read/4568241/pengertiankomik-menurut-para-ahli-lengkap-contoh-contohnya Pada tanggal 4 Februari 2021 pukul 18.50 WIB

Webtoon, Line. (2020). The Editors. Diakses dari https://www.webtoons.com/id/drama/the-editors/tips-membuatwebtoon/viewer?title_no=1870\&episode_no $=5$ Pada tanggal 16 Februari 2021 pukul $21.00 \mathrm{WIB}$ 